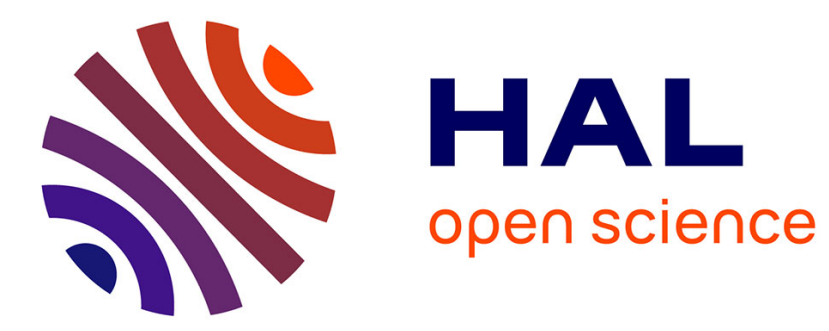

\title{
Role of the androgen receptor in the central nervous system
}

Sakina Mhaouty-Kodja

\section{To cite this version:}

Sakina Mhaouty-Kodja. Role of the androgen receptor in the central nervous system. Molecular and Cellular Endocrinology, 2018, 465, pp.103-112. 10.1016/j.mce.2017.08.001 . hal-01585226

\section{HAL Id: hal-01585226 https://hal.sorbonne-universite.fr/hal-01585226}

Submitted on 11 Sep 2017

HAL is a multi-disciplinary open access archive for the deposit and dissemination of scientific research documents, whether they are published or not. The documents may come from teaching and research institutions in France or abroad, or from public or private research centers.
L'archive ouverte pluridisciplinaire HAL, est destinée au dépôt et à la diffusion de documents scientifiques de niveau recherche, publiés ou non, émanant des établissements d'enseignement et de recherche français ou étrangers, des laboratoires publics ou privés. 


\section{Title}

Role of the androgen receptor in the central nervous system

\section{Author name and affiliation}

Sakina Mhaouty-Kodja

Sorbonne Universités, UPMC Univ Paris 06, INSERM, CNRS, Neuroscience Paris Seine Institut de Biologie Paris Seine. 7 quai St Bernard, 75005 Paris, France.

Tel: +33144279138

Fax: +33144272508

e.mail: sakina.mhaouty-kodja@upmc.fr 


\begin{abstract}
The involvement of gonadal androgens in functions of the central nervous system was suggested for the first time about half a century ago. Since then, the number of functions attributed to androgens has steadily increased, ranging from regulation of the hypothalamicpituitary-gonadal axis and reproductive behaviors to modulation of cognition, anxiety and other non-reproductive functions. This review focuses on the implication of the neural androgen receptor in these androgen-sensitive functions and behaviors.
\end{abstract}

\title{
Key words
}

Androgen receptor; Nervous system; Brain; Behavior; Sex steroid; Hormone 


\section{Introduction}

Androgens have been shown to regulate several neural functions ranging from reproduction to mood and cognitive abilities. This property starts as early as the perinatal period, which is characterized by prenatal and postnatal surges of gonadal testosterone, and continues through puberty and even adulthood. In the nervous system, the effects of testosterone are mediated either by androgen receptors (AR), or, after neural aromatization to $17 \beta$-estradiol, by estrogen receptors (ER) $\alpha$ and ER $\beta$. Local synthesis of neuro-steroids has been reported in several cerebral regions such as the hippocampus, where they modulate hippocampal synaptic plasticity and healthy memory processes (Ooishi et al., 2012). AR and ER receptors are members of the nuclear receptor superfamily and act mainly through regulation of target genes at the transcriptional level, although several studies show rapid membrane and cytoplasmic changes. The present review focuses on studies in rodents that address the neural AR role in androgen-induced regulation of central nervous system (CNS) functions.

\section{Pharmacological and genetic tools to assess neural AR function}

\subsection{Pharmacological tools}

To discriminate between the androgenic and estrogenic pathways in testosterone-mediated regulation of CNS functions, gonadectomy and supplementation with 5- $\alpha$-dihydrotestosterone (DHT) are used. However, this non-aromatizable metabolite of testosterone does not exclusively activate AR. Indeed, it can be metabolized to $5 \alpha$-androstan- $3 \beta$, which binds ERs and triggers neural responses (Handa et al., 2008). Systemic or local treatments in specific CNS regions with AR-antagonists, such as flutamide and cyproterone acetate, are also used to confirm an AR-dependent mechanism. These anti-androgens can act as partial agonists for neural AR in some situations (Nguyen et al., 2007). The use of selective AR modulators (SARM; Narayanan et al., 2017) has also been reported in a few studies. 


\subsection{Genetic models}

Table 1 summarizes the different models used or generated in order to delineate the role of $A R$ gene in CNS functions. The Testicular Feminization Mutation (Tfm) of the AR gene, which resides on the $\mathrm{X}$ chromosome, has been described in both rats and mice (Allison et al., 1971; Lyon \& Hawkes, 1970). These spontaneous genetic models are widely used in studies addressing neural AR functions. Both rat and mouse mutations result in a similar, entirely feminine, external phenotype, but they inactivate $A R$ to different extents. The rat mutation decreases AR function by $85-90 \%$ (Yarbrough et al., 1990). In the mouse model, a single nucleotide deletion introduces a reading frame shift and premature stop codon, thereby resulting in a shortened transcript and absence of AR protein (Charest et al., 1991; He et al., 1991). High testosterone levels are reported in Tfm rats while almost no secretion occurs in mutant mice (Yarbrough et al., 1990).

The global $A R$ knock-out mouse models generated by Cre recombinase-mediated excision of Exon 1 or 2 display an androgen insensitivity phenotype comparable to that of Tfm mice (De Gendt et al., 2004; Sato et al., 2003; Yeh et al., 2002). Genetic (XY) males exhibit a typical female external appearance, small cryptorchidic azoospermic testes and very low levels of circulating testosterone. In both Tfm and global knock-out mice, it is difficult to distinguish between CNS and peripheral-mediated effects of testosterone through the AR, given the critical role of this hormone in several peripheral functions related, or not, to reproduction. This observation motivated the generation of the first mouse line selectively invalidated for the neural $A R$ by using mice with floxed $A R$ Exon 2 and transgenic animals carrying Cre recombinase driven by the nestin promoter and nervous system-specific enhancer (Raskin et al., 2009; Figure 1). This conditional mutation, targeting $A R$ in neuronal and glial precursor cells as early as embryonic day (ED) 10.5, does not interfere with the normal development of 
the urogenital tract. The same mouse line was generated and reported by other groups (Chen et al., 2016; Juntti et al., 2010; Karlsson et al., 2016). Deletion of the $A R$ gene in neurons was also performed using synapsin-I-Cre transgenic mice (Yu et al., 2013). Two mouse models overexpressing $A R$ either globally or selectively at neural sites (neuronal and glial) were recently reported by Swift-Gallant et al. (2016a).

\section{Neuroendocrine functions and behavior related to reproduction}

Perinatal testosterone permanently potentiates male (masculinization) and inhibits female (defeminization) neuroanatomical and behavioral characteristics (Morris et al., 2004; Phoenix et al., 1959). These organizational effects of testosterone suppress the neuroanatomical characteristics required for sex steroids to induce the ovulatory surge of luteinizing hormone (LH) during adulthood (Corbier 1985; Homma et al., 2009). Sex steroids regulate gonadotropin release through an inhibitory or stimulatory feedback effect. Both male and female rodents respond to negative feedback, but only females respond to the positive feedback effect. The perinatal action of testosterone also triggers the adult expression of maletypical behavior (such as a preference for a receptive female, mounts and thrusts) and an inability to adopt the female posture (lordosis), which is triggered by male mounts (Phoenix et al., 1959; Baum et al., 1990). The pubertal testosterone increase also seems to be involved in the final maturation of neural structures underlying reproductive functions (Ahmed et al., 2008; De Lorme et al., 2012, 2016; Schulz et al., 2004). During adulthood, testosterone acts transiently on cerebral areas by exerting an activational role on neuroendocrine functions and behavior.

\subsection{The hypothalamic-pituitary-gonadal (HPG) axis}


The HPG axis plays a crucial role in steroid hormone production. In males, the testicular synthesis of testosterone is under the control of the hypothalamic gonadotropin-releasing hormone $(\mathrm{GnRH})$ and pituitary LH. The liberated testosterone acts in turn to reduce GnRH release and thereby control gonadotropin secretion. In the hypothalamus, the negative feedback exerted by testosterone does not seem to directly target GnRH neurons, since these cells lack AR and ER $\alpha$. Negative feedback seems to occur upstream of the GnRH neurons at the level of the kisspeptin system. This system acts as a CNS regulator of the HPG axis and is currently considered to be a key target of testosterone feedback regulation for GnRH and LH release (Navarro et al., 2011; Raskin et al., 2009; Ruka et al., 2016; Smith et al., 2005). Kisspeptin neurons are localized in two hypothalamic regions. The rostral periventricular area of the third ventricle involved in the ovulatory surge of LH in females contains fewer cells in males due to its perinatal masculinization by testosterone (Clarkson \& Herbison 2006, 2009). The arcuate nucleus integrates the negative feedback exerted by sex steroid hormones in both sexes. In male mice, testosterone-induced regulation of KiSS- 1 expression has been shown to involve ER $\alpha$ and AR, which are both co-expressed in most KiSS-1 neurons of the arcuate nucleus (Smith et al., 2005). In the arcuate nucleus, kisspeptin is co-expressed with neurokinin B, another major regulator of GnRH neurons (Navarro et al., 2009). Extracellular recording of brain slices from intact or castrated and treated males showed that agonists of both $\mathrm{ER} \alpha$ and $\mathrm{AR}$ inhibit the neuronal response to activation of the neurokinin-3 receptor in adult mice (Ruka et al., 2016). However, data from global ER $\alpha$ knock-out mice suggested that the cerebral AR could play the primary physiological role in steroid feedback of LH secretion (Wersinger et al., 1999). Neural $A R$ knock-out males exhibit elevated levels of circulating LH and testosterone (Raskin et al., 2009), indicating the involvement of hypothalamic AR in the negative regulation of the HPG axis. In contrast, neural AR does not seem to be involved in the perinatal organization of the rostral periventricular area of the third ventricle nucleus, 
since the number of kisspeptin neurons was similar in control and mutant littermates (Table 2; Picot et al., 2014). This suggests that neural AR might be involved in the activational but not in organizational regulation of the HPG axis by testosterone.

\subsection{Reproductive behavior}

In rodents, reproductive behavior is induced by olfactory cues. Pheromone cues emitted by a sexually receptive female are detected by the main olfactory epithelium and vomeronasal organ of the male and are transmitted, respectively, to the main and accessory olfactory bulbs, then to chemosensory responsive nuclei in the medial amygdala, to the stria terminalis bed nucleus and the medial preoptic area, where they are processed into behavioral responses (Figure 2). Projections are sent from the hypothalamic paraventricular nucleus to spinal centers that promote penile erection and ejaculation like the spinal nucleus of the bulbocavernosus (SNB) and the gastrin-releasing peptide system. During the perinatal period, the organizational effects of testosterone result in sex differences at the structural, neurochemical and molecular levels along this circuitry (Morris et al., 2004). The widely-described sex differences in cell number and morphology or fiber density in these brain areas underlie the behavioral differences observed during adulthood.

\subsubsection{AR expression in neural structures underlying reproductive behavior}

In adult rats and mice, a high level of mRNA and protein expression occurs in the medial amygdala, lateral septum, stria terminalis bed nucleus, preoptic area and ventromedial hypothalamus (Pelletier, 2000; Raskin et al., 2009; Simerly et al., 1990). The AR is also present in the cerebellum, with a high expression level in superficial Purkinje neurons of the vermis (Perez-Pouchoulen et al., 2016; Simerly et al., 1990), where specific regions of the 
cerebellar vermis become active during sexual behavior in rats (Garcia-Martinez et al., 2010; Manzo et al., 2008).

In the developing mouse hypothalamus, AR mRNA concentrations increase from ED 19 to postnatal day (PND) 7 and then decrease in both males and females, but with a higher expression level in males (Mogi et al., 2015). Mice carrying a knock-in $A R$ allele, which permits co-expression of the nuclear $\beta$-galactosidase reporter gene, showed that at PND $4, \mathrm{AR}$ expression is detected in the arcuate nucleus and ventral hypothalamus, but not in the medial amygdala, preoptic area and bed nucleus of stria terminalis, where only few AR-positive cells are present (Juntti et al., 2010). This number increases from PND 7 onwards in a sexually dimorphic manner. In line with these data, AR immunoreactivity was low in the early postnatal hypothalamus (anteroventral periventricular area, preoptic area, arcuate nucleus) of both males and females and strongly increased from PND 5 in male mice compared to females (Brock et al., 2015). In the SNB motoneurons, AR immunoreactivity is detected from PND 7 in both rats (Jordan 1997) and mice (Smith et al., 2012). These concordant data indicate that neural AR expression starts to increase after the perinatal period, meaning that the involvement of this receptor in the perinatal organizational effects of testosterone is unlikely.

\subsubsection{Regulation of sexual behavior}

In rodents, sexual behavior comprises pre-copulatory and copulatory phases. During the precopulatory (motivational) phase, the courting male displays a chemo-investigating behavior towards receptive females and produces ultrasonic vocalizations. The emission of these latter during courtship plays a role in attracting the female partner (Pomerantz et al., 1983). During the copulatory or consumatory phase, the male exhibits mounting, thrusting, and intromitting 
behavior before reaching ejaculation. The studies addressing AR implication in each of these are summarized and discussed below.

\subsubsection{Pre-copulatory behavior}

Olfactory preference. Data from Tfm mice suggested a major role of AR in olfactory partner preference (Bodo \& Rissman, 2007). However, further studies did not confirm these observations. Tfm male rats exhibit a normal preference for estrous females, suggesting that partner preference is normally masculinized (Hamson et al., 2009). Naïve and sexually experienced males lacking neural $A R$ also display normal olfactory preference (Marie-Luce et al., 2013; Raskin et al., 2009). In line with these data, neural $A R$ overexpression resulted in normal anogenital investigation and olfactory preference towards females. In contrast, global $A R$ overexpression increased both behavioral patterns (Swift-Gallant et al., 2016a; 2016b). In neural conditional knock-out models, no differences were seen upon neuronal activation mapped by Fos-immunoreactivity, following exposure to estrus female-soiled bedding (Raskin et al., 2009; Swift-Gallant et al., 2016b). This discrepancy between global $A R$ gene alteration (Tfm and $\mathrm{AR}$ overexpression) and neural $A R$ mutations (deletion or overexpression) suggests that androgens may act through non-neural AR to trigger olfactory preference, as was recently proposed (Swift-Gallant et al., 2016a; 2016b). Alternatively, global $A R$ gene alteration may alter other signaling pathways involved in testosterone-mediated regulation of olfactory preferences, such as ER $\alpha$ (Wersinger \& Rissman, 2000). Complex regulation of odor preference by sex steroids was suggested by a previous rat study showing that AR blockade by flutamide in the posterodorsal medial amygdala seemed to induce a preference for male odors rather than reduce a preference for female odors (Hosokawa \& Shiba, 2010). 
Sexual arousal. Noncontact penile erection occurring in the male rat exposed to female odors or inaccessible sexually receptive females represent a useful model to assess sexual arousal. Previous studies pointed out a role for androgens, but not for estrogens, in this behavior (Cooke et al., 2003; Manzo et al., 1999). Further studies suggested that the medial amygdala is one of the neuronal structures that regulate male sexual arousal. Indeed, of males that received flutamide implants in the medial amygdala, fewer exhibited non-contact erections. Such males displayed longer latencies before their first sexual comportment and had less noncontact erections. Furthermore, they spent less total time in genital grooming in comparison to the control group (Bialy et al., 2011).

Sexual arousal can also be indexed by ultrasonic mating calls. In this context, it has been shown that castration and testosterone supplementation influence the production of courtship vocalization in male mice (Dizinno \& Whitney, 1977). Treatment combining DHT and estradiol increased vocalizations in the same way as testosterone (Nunez et al., 1978). More recently, we have shown that neural $A R$ knock-out males emit fewer and shorter vocalizations in the presence of sexually receptive females compared to their control littermates (Dombret et al., in press). The estrous state of the female must be important in eliciting this behavior, since neural AR mutants were shown to vocalize normally in the presence of intruder females (Juntti et al., 2010). It remains to be studied whether neural AR acts in the preoptic nucleus to increase the motivation to vocalize (Bean et al., 1982) or in the motor system (cortex, striatum, thalamus) to modulate vocalizations.

\subsubsection{Copulatory behavior}

Tfm rats show infrequent and incomplete copulatory responses to receptive females (Beach \& Buehler, 1977), but exhibit normal mounting behavior and latency to mount (Hamson et al., 2009; Olsen 1979). More recent studies in Tfm mice reported a minor contribution of the 
neural AR in the display of sexual behavior (Bodo \& Rissman, 2007; Scordalakes \& Rissman, 2004), while a major role was suggested from the analysis of global knock-out males (Sato et al., 2004). In these models, sexual behavior is limited to mounting and thrusting behavior due to the lack of external genitals (Ono et al., 1974; Sato et al., 2004). Therefore, conditional mouse models were analyzed to evaluate more precisely the neural contribution of androgens through $\mathrm{AR}$ in the display of full sexual behavior. Male mice lacking neural $A R$ displayed increased latency to initiate mounting, thrusting and intromitting behavior and to reach ejaculation (Picot et al., 2014; Raskin et al., 2009; Raskin et al., 2012). The number of mounts with intromissions and total thrusts were also reduced. These behavioral alterations were seen in either intact or castrated mutants supplemented with testosterone to normalize their hormonal levels, and were maintained after sexual experience (Figure 3). Conversely, neural $A R$ overexpression increased mounting and thrusting (Swift-Gallant et al., 2016a). The fact that neural $A R$ invalidation did not affect olfactory preference strongly suggests that the sexual deficiency of neural $A R$ knock-out males is caused by altered neural function in chemosensory responsive regions downstream from the olfactory bulb. Table 2 summarizes the analyses undertaken in the neural $A R$ knock-out mouse model to determine whether the behavioral alterations were due to altered neuroanatomical organization. Interestingly, neural $A R$ mutation did not affect neuronal populations such as the sexually dimorphic calbindin cluster, which is known to be organized by perinatal testosterone. Similarly, the perinatal organization of SNB motoneuron number was not altered by neural $A R$ mutation. This confirms previous conclusions that testosterone-mediated sparing of SNB motor neurons from atrophy may depend upon peripheral AR action in the bulbo-cavernosus/levator ani muscles where this receptor is expressed from ED 15 onwards (Breedlove \& Arnold, 1983; Smith et al., 2012). In contrast, SNB motoneuron soma size and dendritic length, which are influenced by testosterone until PND 12 and 28 (Breedlove \& Arnold, 1983; Goldstein et al., 1990), were 
reduced in mutant males lacking neural $A R$. Again, this suggests that neural $A R$ mediates the postnatal, but not perinatal, effects of testosterone. Neural AR was also found to regulate gastrin-releasing peptide expression, as evidenced by the lower neuron number and intensity of axonal projections in neural $A R$ knock-out male mice (Sakamoto et al., 2014). Whether this regulation involves developmental or adult AR effects is not known. Although the behavioral deficits observed in neural $A R$ knock-out male mice indicate that this receptor is important, the precise period(s) of action (postnatal, pre-pubertal, pubertal or adult) still need to be identified using dedicated models. In a recent study, the subcutaneous treatment of male rats with flutamide during the first week postnatal had no effect on sexual behavior, whereas continuous treatment during the two first weeks altered intromission and ejaculation but not mounting behavior (Yamada et al., 2015).

\subsubsection{Aggressive behavior}

A comparison of wild-type and Tfm mice, which were gonadectomized and implanted with estradiol-containing implants, showed a minor difference in the display of aggressive behavior (Bodo \& Rissman, 2007; Scordalakes \& Rissman, 2004). In contrast, gonadally intact Tfm mice given a vehicle or anabolic androgenic steroids exhibited fewer aggressive events than wild-type males (Robinson et al., 2012). The major role of AR in the display of aggressive behavior was also shown in neural $A R$ knock-out males (Raskin et al., 2009; Marie-Luce et al., 2013). In the resident-intruder paradigm, a low percentage of mutant males exhibited offensive attacks towards intruder mice compared to control littermates, despite normal anogenital chemo-investigation of intruders. The latency time to the first attack was increased, while the total aggression duration and the number of attacks were greatly reduced in mutant males. This less aggressive behavior was confirmed by further analyses of a similar neural $A R$ knock-out model (Juntti et al., 2010; Studer et al., 2015). In social preference and 
recognition tests, neural $A R$ knock-out male mice showed normal social investigation but failed to recognize male conspecifics (Karlsson et al., 2016).

Arginine-vasopressin is a key neuromodulator of social behavior. The neuronal cell population expressing this peptide in the bed nucleus of stria terminalis is known to be sexually dimorphic and organized through the perinatal action of testosterone. Neural $A R$ mutants showed comparable arginine-vasopressin cell numbers in the bed nucleus of stria terminalis and fiber density in the septum to those of their control littermates (Table 2). No modification was seen in the amount of galanin, a neuropeptide co-expressed with argininevasopressin. Neural AR does not seem to be involved in the perinatal organization of these brain areas that are essential for aggression, but may be implicated in adult activational effects of testosterone. In the territorial California mouse, winning fights increases the expression of $\mathrm{AR}$ in the bed nucleus of the stria terminalis, but also in brain regions that mediate motivation and reward such as the accumbens nucleus and the ventral tegmental area (Fuxjager et al., 2010). In Neotropical singing mice, the supplementation of castrated males with testosterone or DHT similarly restores both aggressive behavior and song effort in male-male aggression, suggesting an activational role of AR in both types of behavior (Pasch et al., 2011).

\section{Cognition}

Estrogen-mediated regulation of cognitive behavior and synaptic plasticity has been largely studied in rodents. In comparison, the neural function of AR has been investigated less thoroughly, although this receptor is expressed to a high level in brain structures that ensure underlying cognitive processes.

\subsection{AR expression}


$\mathrm{AR}$ is expressed in the adult cortex and hippocampus where it is predominantly expressed in Cornu Ammonis (CA) 1 and CA2/3 regions (Kerr et al., 1995; Kritzer 2004; Raskin et al., 2009; Simerly et al., 1990). Combined retrograde tracing and immuno-labeling of AR showed the prefrontal cortex to ventral tegmental area projection to be AR-enriched (Aubele \& Kritzer, 2012). As a transcription factor, the AR protein is generally found in the nucleus, but by electron microscopy AR immunoreactivity was also revealed in axons and dendrites of the amygdala and cerebral cortex (DonCarlos et al., 2003; 2006). In these non-classical sites, AR may play roles in rapid behavioral effects of androgens.

In the developing male rat hippocampus, AR mRNA concentrations were shown to increase progressively from PND 1 to PND 14 and were then maintained until adulthood (Kimoto et al., 2010). Similar data were reported in mice where hippocampal mRNA concentrations significantly increased from basal levels at PND 5 in males and PND 1 in females through PND 7 (Mogi et al., 2015). In the same mouse study, cortical transcript concentrations increased significantly from ED 19 to PND 7 in both sexes. A more recent study confirmed the progressive increase in AR mRNA concentrations from PND 0 to PND 21 in the mouse cortex and hippocampus of both sexes (Tsai et al., 2015).

The predominant cellular phenotype of AR-immuno-reactive cells in the developing and adult male rat forebrain is neuronal, but populations of AR-positive astrocytes also exist in discrete locations and at specific ages (Lorenz et al., 2005).

\subsection{Behavioral, morphological and functional analyses}

The neural role of AR in learning and memory processes was first suggested by intrahippocampal infusions of DHT to gonadectomized male rats (Edinger \& Frye, 2004). In the same way as for testosterone, DHT supplementation improved learning by treated males compared to vehicle controls in the inhibitory avoidance task. In the Morris water maze 
(MWM), assessing spatial learning and memory, the performance of Tfm rats was intermediate between that of normal males and females, suggesting partial masculinization of this behavior through AR (Jones et al., 2005). In the Tfm mouse model, a greater role for AR in spatial learning and memory was supported by data showing that genetic XY animals underperform females in the MWM (Rizk et al., 2005). An AR blockade in the dorsal hippocampus interfered with cognitive performance in the inhibitory avoidance and MWM tasks by the male rat (Edinger \& Frye, 2007). In particular, immediate administration of flutamide to the dorsal hippocampus at both pre- and post-training times induced a significantly poorer performance, while a simple injection 2 hours after training had no effect. Combined treatment with a SARM (ACP-105) and ER $\beta$ agonist improved cognitive performance in the MWM by gonadectomized male triple transgenic mice overexpressing both the human amyloid precursor protein presenilin 1 and tau and exhibiting the features of Alzheimer's disease (George et al., 2013). Finally, treatment with testosterone attenuated spatial memory defects in the MWM induced by castration (Moghadami et al., 2016) and increased the density of AR-immuno-reactive neurons in the hippocampus areas (Moghadami et al., 2016, Qiu et al., 2016). In a recent study, using conditional neural $A R$ knock-out mice, we addressed temporal processing of information (Picot et al., 2016). This is the ability to remember the order in which items or events have been experienced. Neural $A R$ invalidation impairs the processing of temporal information for visual objects and alters glutamatergic transmission in the hippocampus CA1 area. Indeed, this mutation affects basal glutamate synaptic transmission and decreases magnitude of N-methyl-D-aspartate receptor (NMDAR) activation and high-frequency stimulation-induced long-term potentiation.

At the cellular and molecular levels, DHT treatment increased $\mathrm{Ca}^{2+}$ stores in response to glutamate through a flutamide-sensitive pathway involving the up-regulation of sarco and endoplasmic reticulum calcium ATPase 2 expression in rat primary hippocampal neurons 
(Foradori et al., 2007). Several studies have suggested that AR mediates the androgeninduced maintenance of normal spine synapse density in the CA1 area and the prefrontal cortex (Hajszan et al., 2007; Hatanaka et al., 2015; Leranth et al., 2003). It modulates the functional properties of pyramidal cells in both the CA1 (Pettorossi et al., 2013; Pouliot et al., 1996) and CA3 areas (Skucas et al., 2013) and increases CA3 dendritic thorns in hippocampal slices (Hatanaka et al., 2009). Hamson et al. (2013) showed that testosterone increases neurogenesis in the dentate gyrus of wild-type but not Tfm rats and that flutamide treatment blocks the DHT-induced increase of hippocampal neurogenesis.

\section{The Hypothalamic-Pituitary-Adrenal (HPA) axis and anxiety-related behavior}

Testosterone has been shown to modulate the HPA response to stress and attenuate anxietylike behavior. In rats, supplementation or intra-hippocampal infusion of gonadectomized males with testosterone or DHT induced a lower anxiety-related behavior in the elevatedplus-maze, open field and defensive freezing tests (Edinger \& Frye, 2004). Intra-hippocampal application of flutamide blocked DHT-induced effects, suggesting an implication of the hippocampal AR in an androgen-induced decrease of anxiety-like behavior (Edinger \& Frye, 2006). In the Tfm rat model, Rizk et al. (2005) reported unchanged anxiety-state level assessed in the elevated-plus-maze and open field tests. In contrast, two other studies reported increased behavioral indices of anxiety in the open-field and elevated plus maze tests for Tfm rats compared to wild-type males and females (Hamson et al., 2014; Zuloaga et al., 2011). Mutant rats exhibited an increased corticosterone peak in response to mild stress, showing a chronic anxiety phenotype and dysregulated HPA axis (Zuloaga et al., 2011). An androgeninduced organization of the HPA axis through both AR and estrogen conversions was supported by data showing that postnatal treatment with flutamide or an aromatase inhibitor interfered with the adult HPA response to repeated stress (Bingham et al., 2011). 
In mice, the Tfm mutation increased the anxiety-state assessed in the novel object and in light/dark box tests, whereas no changes were detected in the open field or elevated plus maze tasks (Zuloaga et al., 2008). As for Tfm rats, this seemed to be related to an increased HPA response to stress. The same group showed that global $A R$ knock-out male mice exhibit similar behavioral deficiencies and HPA dysregulation (Chen et al., 2014). An elevated anxiety-state, in particular during the light phase, was seen in the open field, novel object and elevated plus maze tests, but not in the light/dark box and corticosterone levels remained high after mild stress. In contrast, neural $A R$ invalidation did not affect androgenic regulation of anxiety or HPA activity (Chen et al., 2016; Raskin et al., 2009; Picot et al., 2016). It has been suggested that in neural $A R$ mutant male mice, this lack of effect may be due to residual $A R$ expression in the amygdala and hypothalamus, but not in the hippocampus or cortex (Chen et al., 2016). Alternatively, AR-expressing sites other than neurons and glial cells may be involved in such effects. Indeed, novel data suggest the involvement of the immune system including microglia cells in the development of anxiety in response to stress (reviewed in Reader et al., 2015).

\section{Other brain functions}

Recent reviews nicely summarize the role of expanded polyQ chain within the first exon of the AR in spinal and bulbar muscular atrophy and recent views on the development of this neurodegenerative disease (Giorgetti \& Lieberman, 2016; Pennuto \& Rinaldi, 2017). Otherwise, several studies documented the implication of androgens in neuroprotection. Pharmacological studies addressing the mechanisms underlying androgen-induced effects showed that pre-treatment of hippocampal neurons with testosterone or DHT, but not with estrogens, reduces cell death induced by different insults (Nguyen et al., 2010). In agreement with these data, the SARM RAD140 exerted a neuroprotective effect in both primary 
hippocampal cells and the hippocampus of kainite lesioned males (Jayaraman et al., 2014). Flutamide counteracted testosterone-induced improvement of dendritic spine density in the hippocampal CA1 region of an Alzheimer's disease mouse animal model (Jia et al., 2016). The AR was also reported to mediate DHT-induced suppression of neuronal injury in rat organotypic hippocampal slice cultures as shown by flutamide treatment (Ishihara et al., 2016). However, in a male mouse model of cerebral ischemia, the AR was found to be involved in both neuroprotective and deleterious effects of androgens (Uchida et al., 2009).

In CNS lesions induced by chronic treatment with toxic agents, testosterone was effective in stimulating the formation of new myelin and in reversing myelin damage in the brain (Hussain et al., 2013). In the ventral spinal cord, it favored astrocyte recruitment and spontaneous oligodendrocyte-mediated re-myelination (Bielecki et al., 2016). Both types of glial cell express the AR. Interestingly, testosterone failed to induce these effects in Tfm mutants and neural $A R$ knock-out mice, indicating a main role of this receptor (Bielecki et al., 2016; Hussain et al., 2013).

Although less documented than the other CNS effects of androgens, a regulatory role of circadian responses has been suggested. This hypothesis was based on high AR expression in the mouse suprachiasmatic nucleus, the brain clock controlling circadian rhythms in physiology and behavior (Iwahana et al., 2008). Hypothalamic implants of testosterone in this nucleus increases AR expression and restores locomotor activity in gonadectomized male mice (Model et al., 2015).

\section{Conclusions and future directions}

Information from in vitro and in vivo models is progressively allowing a more precise view of the neural role of AR in rodents. This helps to open and consider new perspectives in human studies since androgens are also suggested to modulate several brain functions related to 
reproduction, cognition, anxiety or neuroprotection in man. However, much remains to be discovered and many questions still need to be addressed. For instance, although the effects of androgens are widely studied in the brain, the mechanisms underlying their effects in each brain area or nucleus still remain to be identified. In particular, AR targets and mediators remain largely unknown. A better knowledge of AR signaling pathways would be of particular relevance in studies of the physiological regulation of reproductive and nonreproductive functions as well as in physio-pathological situations such as exposure to anabolic androgenic steroids or endocrine disrupters with anti-androgenic activities. Furthermore, AR is expressed not only in neurons but also in glial cells including astrocytes, oligodendrocytes and microglia, which play a key role in brain physiology and behavior. Models targeting $A R$ expression in each of these cell types would be of great help. Finally, more studies are needed in females. Although expressed to a lesser extent than in males, AR is present in the female brain, but its role in female brain physiology is not yet clear. 


\section{Acknowledgments}

This work was supported by grants from the "Agence Nationale de la Recherche" ANR-09CESA-006 program, the Agence nationale de sécurité sanitaire de l'alimentation, de l'environnement et du travail (Anses, Project $\mathrm{n}^{\circ}$ 2012-2-077) and the Interdisciplinary Program "Longévité et Vieillissement" of the CNRS. 


\section{References}

Ahmed EI, Zehr JL, Schulz KM, Lorenz BH, DonCarlos LL, Sisk CL. Pubertal hormones modulate the addition of new cells to sexually dimorphic brain regions. Nat Neurosci. 2008, 11:995-997.

Allison JE, Chan F, Stanley AJ, Gumbreck LG. Androgen insensitivity in male pseudohermaphrodite rats. Endocrinology 1971, 89:615-617.

Aubele T, Kritzer MF. Androgen influence on prefrontal dopamine systems in adult male rats: Localization of cognate intracellular receptors in medial prefrontal projections to the ventral tegmental area and effects of gonadectomy and hormone replacement on glutamate-stimulated extracellular dopamine level. Cereb Cortex. 2012, 22:1799-1812.

Baum M.J, Erskine MS, Kornberg E, Weaver CE. Prenatal and neonatal testosterone exposure interact to affect differentiation of sexual behavior and partner preference in female ferrets. Behav. Neurosci. 1990, 104:183-198.

Beach FA, Buehler MG. Male rats with inherited insensitivity to androgen show reduced sexual behavior. Endocrinology 1977, 100:197-200.

Bean NJ. Olfactory and vomeronasal mediation of ultrasonic vocalizations in male mice. Physiol. Behav. 1982, 28:31-37.

Bialy M, Nikolaev-Diak A, Kalata U, Nikolaev E. Blockade of androgen receptor in the medial amygdala inhibits noncontact erections in male rats. Physiol Behav. 2011, 103:295301.

Bielecki B, Mattern C, Ghoumari Abdel, Javaid S, Smietanka K, Abi Ghanem C, MhaoutyKodja S, Ghandour S, Baulieu EE, Franklin RJM, Schumacher M, and Traiffort E. The spontaneous regeneration of myelin: an unexpected central role of the androgen receptor. Proc Natl Acad Sci U S A. 2016, 113:14829-14834. 
Bingham B, Gray M, Sun T, Viau V. Postnatal blockade of androgen receptors or aromatase impair the expression of stress hypothalamic-pituitary-adrenal axis habituation in adult male rats. Psychoneuroendocrinology 2011, 36:249-257.

Bodo C, Rissman EF. Androgen receptor is essential for sexual differentiation of responses to olfactory cues in mice. Eur J Neurosci. 2007, 25:2182-2190.

Breedlove SM, Arnold AP. Hormone accumulation in a sexually dimorphic motor nucleus of the rat spinal cord. Science 1980, 210:564-566.

Breedlove SM, Arnold AP. Hormonal control of a developing neuromuscular system. II. Sensitive periods for the androgen-induced masculinization of the rat spinal nucleus of the bulbocavernosus. J Neurosci. 1983, 3:424-432.

Brock O, De Mees C, Bakker J. Hypothalamic Expression of Oestrogen Receptor a and Androgen Receptor is Sex-, Age- and Region-Dependent in Mice. J Neuroendocrinol. 2015, 27:264-276.

Charest NJ, Zhou ZX, Lubahn DB, Olsen KL, Wilson EM, French, F.S. A frameshift mutation destabilizes androgen receptor messenger RNA in the Tfm mouse. Mol Endocrinol. 1991, 5:573-581.

Chen CV, Brummet JL, Jordan CL, Breedlove SM. Down, but not out: Partial elimination of androgen receptors in the male mouse brain does not affect androgenic regulation of anxiety or HPA activity. Endocrinology 2016, 157:764-773.

Chen CV, Brummet JL, Lonstein JS, Jordan CL, Breedlove SM. New knockout model confirms a role for androgen receptors in regulating anxiety-like behaviors and HPA response in mice. Horm Behav. 2014, 65:211-218.

Clarkson J, Herbison AE. Oestrogen, kisspeptin, GPR54 and the pre-ovulatory luteinising hormone surge. J. Neuroendocrinol. 2009, 21:305-311. 
Clarkson J, Herbison AE. Postnatal development of kisspeptin neurons in mouse hypothalamus; sexual dimorphism and projections to gonadotropin-releasing hormone neurons. Endocrinology 2006, 147:5817-5825.

Cohen P, Zhao C, Cai X, Montez JM, Rohani SC, Feinstein P, Mombaerts P, Friedman JM. Selective deletion of leptin receptor in neurons leads to obesity. J Clin Invest. 2001,108:1113-1121.

Cooke BM, Breedlove SM, Jordan CL. Both estrogen receptors and androgen receptors contribute to testosterone-induced changes in the morphology of medial amygdala and sexual arousal in male rats. Horm Behav. 2003, 43:336-346.

Corbier P. Sexual differentiation of positive feedback: effect of hour of castration at birth on estradiol-induced luteinizing hormone secretion in immature male rats. Endocrinology $1985,116: 142-147$

De Gendt K, Swinnen JV, Saunders PT, Schoonjans L, Dewerchin M, Devos A, Tan K, Atanassova N, Claessens F, Lecureuil C, Heyns W, Carmeliet P, Guillou F, Sharpe RM, Verhoeven G. A Sertoli cell-selective knockout of the androgen receptor causes spermatogenic arrest in meiosis. Proc Natl Acad Sci U S A 2004, 101:1327-1332.

De Lorme KC, Schulz KM, Salas-Ramirez KY, Sisk CL. Pubertal testosterone organizes regional volume and neuronal number within the medial amygdala of adult male Syrian hamsters. Brain Res. 2012, 1460:33-40.

De Lorme KC, Sisk CL. The organizational effects of pubertal testosterone on sexual proficiency in adult male Syrian hamsters. Physiol Behav. 2016, 165:273-277.

De Vries GJ, al-Shamma HA. Sex differences in hormonal responses of vasopressin pathways in the rat brain. J Neurobiol. 1990, 21:686-693.

Dizinno G, Whitney G. Androgen influence on male mouse ultrasounds during courtship. Horm Behav. 1977, 8:188-192. 
Dombret C, Capela D, Poissenot K, Parmentier C, Bergsten E, Pionneau C, Chardonnet S, Grange-Messent V, Keller K, Franceschini I, Mhaouty-Kodja S. Neural mechanisms underlying disruption of male courtship behavior by adult exposure to di-(2ethylexyl)phthalate in mice. Environ Health Perspect. In press. DOI number: 10.1289/EHP1443.

DonCarlos LL, Sarkey S, Lorenz B, Azcoitia I, Garcia-Ovejero D, Huppenbauer C, GarciaSegura LM. Novel cellular phenotypes and subcellular sites for androgen action in the forebrain. Neuroscience 2006, 138:801-807.

DonCarlos, L.L., Garcia-Ovejero, D., Sarkey, S., Garcia-Segura, L.M., Azcoitia, I. Androgen receptor immunoreactivity in forebrain axons and dendrites in the rat. Endocrinology 2003, $144: 3632-3638$

Edinger KL, Frye CA. Androgens' performance-enhancing effects in the inhibitory avoidance and water maze tasks may involve actions at intracellular androgen receptors in the dorsal hippocampus. Neurobiol Learn Mem. 2007, 87:201-208.

Edinger KL, Frye CA. Intrahippocampal administration of an androgen receptor antagonist, flutamide, can increase anxiety-like behavior in intact and DHT-replaced male rats. Horm Behav. 2006, 50:216-222.

Edinger KL, Frye CA. Testosterone's analgesic, anxiolytic, and cognitive-enhancing effects may be due in part to actions of its 5alpha-reduced metabolites in the hippocampus. Behav Neurosci. 2004, 118:1352-1364.

Foradori CD, Werner SB, Sandau US, Clapp TR, Handa RJ. Activation of the androgen receptor alters the intracellular calcium response to glutamate in primary hippocampal neurons and modulates sarco/endoplasmic reticulum calcium ATPase 2 transcription. Neuroscience 2007, 149:155-164. 
Fuxjagera MJ, Forbes-Lorman RM, Coss DJ, Auger CJ, Auger AP, and Marler CA. Winning territorial disputes selectively enhances androgen sensitivity in neural pathways related to motivation and social aggression. Proc Natl Acad Sci U S A. 2010, 107:12393-12398.

Garcia-Martinez R, Miquel M, Garcia LI, Coria-Avila GA, Perez CA, Aranda-Abreu GE, Toledo R, Hernandez ME, Manzo J. Multiunit recording of the cerebellar cortex, inferior olive, and fastigial nucleus during copulation in naive and sexually experienced male rats, Cerebellum 2010, 9:96-102.

George S, Petit GH, Gouras, GK, Brundin P, Olsson R. Nonsteroidal Selective Androgen Receptor Modulators and Selective Estrogen Receptor $\beta$ Agonists Moderate Cognitive Deficits and Amyloid- $\beta$ Levels in a Mouse Model of Alzheimer's Disease. ACS Chem. Neurosci. 2013, 4:1537-1548.

Giorgetti E, Lieberman AP. Polyglutamine androgen receptor-mediated neuromuscular disease. Cell Mol Life Sci. 2016, 73:3991-3999.

Goldstein LA, Kurz EM, Sengelaub DR. Androgen regulation of dendritic growth and retraction in the development of a sexually dimorphic spinal nucleus. J Neurosci. 1990, 10:935-946.

Hajszan T, MacLusky NJ, Johansen JA, Jordan CL, Leranth C. Effects of androgens and estradiol on spine synapse formation in the prefrontal cortex of normal and testicular feminization mutant male rats. Endocrinology 2007, 148:1963-1967.

Hamson DK, Csupity AS, Ali FM, Watson NV. Partner preference and mount latency are masculinized in androgen insensitive rats. Physiol Behav. 2009, 98:25-30.

Hamson DK, Jones BA, Csupity AS, Ali FM, Watson NV. Androgen insensitive male rats display increased anxiety-like behavior on the elevated plus maze. Behav Brain Res. 2014, 259:158-163. 
Hamson DK, Wainwright SR, Taylor JR, Jones BA, Watson NV, and Galea LAM. Androgens increase survival of adult-born neurons in the dentate gyrus by an androgen receptordependent mechanism in male rats. Endocrinology 2013, 154: 3294-3304.

Handa RJ, Pak TR, Kudwa AE, Lund TD, Hinds L. An alternate pathway for androgen regulation of brain function: activation of estrogen receptor beta by the metabolite of dihydrotestosterone, 5alpha-androstane-3beta,17beta-diol. Horm Behav. 2008, 53:741-752.

Hatanaka Y, Hojo Y, Mukai H, Murakami G, Komatsuzaki Y, Kim J, Ikeda M, Hiragushi A, Kimoto T, Kawato S. Rapid increase of spines by dihydrotestosterone and testosterone in hippocampal neurons: Dependence on synaptic androgen receptor and kinase networks. Brain Res. 2015, 1621:121-132.

Hatanaka Y, Mukai H, Mitsuhashi K, Hojo Y, Murakami G, Komatsuzaki Y, Sato R, Kawato S. Androgen rapidly increases dendritic thorns of CA3 neurons in male rat hippocampus. Biochem Biophys Res Commun. 2009, 381:728-732.

He WW, Kumar MV, Tindall DJ. A frame-shift mutation in the androgen receptor gene causes complete androgen insensitivity in the testicular-feminized mouse. Nucleic Acids Res. 1991, 19:2373-2378.

Homma T, Sakakibara M, Yamada S, Kinoshita M, Iwata K, Tomikawa J, Kanazawa T, Matsui H, Takatsu Y, Ohtaki T, Matsumoto H, Uenoyama Y, Maeda K, Tsukamura H. Significance of neonatal testicular sex steroids to defeminize anteroventral periventricular kisspeptin neurons and the GnRH/LH surge system in male rats. Biol Reprod. 2009, $81: 1216-1225$.

Hosokawa N, Chiba A. Androgen receptor blockade in the posterodorsal medial amygdala impairs sexual odor preference in male rats. Horm Behav. 2010, 58:493-500.

Hussain R, Ghoumari AM, Bielecki B, Steibel J, Boehm N, Liere P, Macklin WB, Kumar N, Habert R, Mhaouty-Kodja S, Tronche F, Sitruk-Ware R, Schumacher M, Ghandour MS. 
The neural androgen receptor: a therapeutic target for myelin repair in chronic demyelination. Brain 2013, 136:132-146.

Ishihara Y, Fujitani N, Sakurai H, Takemoto T, Ikeda-Ishihara N, Mori-Yasumoto K, Nehira T, Ishida A, Yamazaki T. Effects of sex steroid hormones and their metabolites on neuronal injury caused by oxygen-glucose deprivation/reoxygenation in organotypic hippocampal slice cultures. Steroids 2016, 113:71-77.

Iwahana E, Karatsoreos I, Shibata S, Silver R. Gonadectomy reveals sex differences in circadian rhythms and suprachiasmatic nucleus androgen receptors in mice. Horm Behav. 2008, 53:422-430.

Jayaraman A, Christensen A, Moser VA, Vest RS, Miller CP, Hattersley G, Pike CJ. Selective androgen receptor modulator RAD140 is neuroprotective in cultured neurons and kainate-lesioned male rats. Endocrinology 2014, 155:1398-13406.

Jia JX, Cui CL, Yan XS, Zhang BF, Song W, Huo DS, Wang H, Yang ZJ. Effects of testosterone on synaptic plasticity mediated by androgen receptors in male SAMP8 mice. J Toxicol Environ Health A. 2016, 79:849-855.

Jones BA, Watson NV. Spatial memory performance in androgen insensitive male rats. Physiol Behav. 2005, 85:135-141.

Jordan C. Androgen receptor (AR) immunoreactivity in rat pudendal motoneurons: implications for accessory proteins. Horm Behav. 1997, 32:1-10

Juntti SA, Tollkuhn J, Wu MV, Fraser EJ, Soderborg T, Tan S, Honda S, Harada N, Shah NM. The androgen receptor governs the execution, but not programming, of male sexual and territorial behaviors. Neuron 2010, 66:260-272.

Karlsson SA, Studer E, Kettunen P, and Westberg L. Neural androgen receptors modulate gene expression and social recognition but not social investigation. Front Behav Neurosci. $2016,10: 41$ 
Kauffman AS, Gottsch ML, Roa J, Byquist AC, Crown A, Clifton DK, Hoffman GE, Steiner RA, Tena-Sempere M. Sexual differentiation of Kiss1 gene expression in the brain of the rat. Endocrinology 2007, 148:1774-1783.

Kerr JE, Allore RJ, Beck SG, Handa RJ. Distribution and hormonal regulation of androgen receptor (AR) and AR messenger ribonucleic acid in the rat hippocampus. Endocrinology $1995 ; 136: 3213-3221$.

Kimoto T, Ishii H, Higo S, Hojo Y, Kawato S. Semicomprehensive Analysis of the Postnatal Age-Related Changes in the mRNA Expression of Sex Steroidogenic Enzymes and Sex Steroid Receptors in the Male Rat Hippocampus. Endocrinology 2010, 151:5795-5806.

Kritzer M. The distribution of immunoreactivity for intracellular androgen receptors in the cerebral cortex of hormonally intact adult male and female rats: localization in pyramidal neurons making corticocortical connections. Cereb Cortex. 2004, 14:268-280.

Leranth C, Petnehazy O, MacLusky NJ. Gonadal hormones affect spine synaptic density in the CA1 hippocampal subfield of male rats. J Neurosci. 2003, 23: 1588-1592.

Lorenz B, Garcia-Segura LM, DonCarlos LL. Cellular phenotype of androgen receptorimmunoreactive nuclei in the developing and adult rat brain. J Comp Neurol. 2005, 492:456-68.

Lyon MF, Hawkes SG. X-linked gene for testicular feminization in the mouse. Nature 1970, 227:1217-1219.

Manzo J, Cruz MR, Hernández ME, Pacheco P, Sachs BD. Regulation of noncontact erection in rats by gonadal steroids. Horm Behav. 1999, 35:264-270.

Manzo J, Miquel M, Toledo R, Mayor-Mar JA, Garcia LI, Aranda-Abreu GE, Caba M, Hernandez ME. Fos expression at the cerebellum following non-contact arousal and mating behavior in male rats. Physiol Behav. 2008, 93:357-363. 
Marie-Luce C, Raskin M, Bolborea M, Monin M, Picot M, Mhaouty-Kodja S. Effects of neural androgen receptor disruption on aggressive behavior and arginine vasopressin system in the bed nucleus of stria terminalis. Gen Comp Endocrinol. 2013, 188:218-225.

Model Z, Butler MP, LeSauter J, Silver R. Suprachiasmatic nucleus as the site of androgen action on circadian rhythms. Horm Behav. 2015, 73:1-7.

Moghadami S, Jahanshahi M, Sepehri H and Amini H. Gonadectomy reduces the density of androgen receptor-immunoreactive neurons in male rat's hippocampus: testosterone replacement compensates it. Behav Brain Funct. 2016, 12:5.

Mogi K, Takanashi H, Nagasawa M, Kikusui T. Sex differences in spatiotemporal expression of AR, ER $\alpha$, and ER $\beta$ mRNA in the perinatal mouse brain. Neurosci Lett. 2015, 584:8892.

Morris JA, Jordan CL \& Breedlove SM. Sexual differentiation of the vertebrate nervous system. Nat Neurosci. 2004, 7:1034-1039.

Narayanan R, Coss CC, Dalton JT. Development of selective androgen receptor modulators (SARMs). Mol Cell Endocrinol. 2017 Jun 15.

Navarro VM, Gottsch M.L, Chavkin C, Okamura H, Clifton DK, Steiner RA. Regulation of gonadotropin-releasing hormone secretion by kisspeptin/dynorphin/neurokinin B neurons in the arcuate nucleus of the mouse. J Neurosci. 2009, 29:11859-11866.

Navarro VM, Gottsch ML, Wu M, García-Galiano D, Hobbs SJ, Bosch MA, Pinilla L, Clifton DK, Dearth A, Ronnekleiv OK, Braun RE, Palmiter RD, Tena-Sempere M, Alreja M, Steiner RA. Regulation of NKB pathways and their roles in the control of Kiss1 neurons in the arcuate nucleus of the male mouse. Endocrinology 2011, 152:4265-4275.

Nguyen TV, Jayaraman A, Quaglino A, Pike CJ. Androgens selectively protect against apoptosis in hippocampal neurones. J Neuroendocrinol. 2010, 22:1013-1022. 
Nguyen TV, Yao M, Pike CJ. Flutamide and cyproterone acetate exert agonist effects: induction of androgen receptor-dependent neuroprotection. Endocrinology 2007, 148:2936-2943.

Nunez AA, Nyby J, Whitney G. 1978. The effects of testosterone, estradiol, and dihydrotestosterone on male mouse (Mus musculus) ultrasonic vocalizations. Horm Behav. $11: 264-272$

Olsen KL. Induction of male mating behavior in androgen-insensitive (tfm) and Normal (King-Holtzman) male rats: effect of testosterone propionate, estradiol benzoate, and dihydrotestosterone. Horm Behav. 1979; 13:66-84.

Ono S, Geller LN, Lai EV. TfM mutation and masculinization versus feminization of the mouse central nervous system. Cell 1974, 3:235-242.

Ooishi Y, Kawato S, Hojo Y, Hatanaka Y, Higo S, Murakami G, Komatsuzaki Y, OgiueIkeda M, Kimoto T, Mukai H. Modulation of synaptic plasticity in the hippocampus by hippocampus-derived estrogen and androgen. J Steroid Biochem Mol Biol. 2012, 131:3751.

Orikasa C, Sakuma Y. Estrogen configures sexual dimorphism in the preoptic area of C57BL/6J and ddN strains of mice. J Comp Neurol. 2010, 518:3618-3629.

Pasch B, George AS, Hamlin HJ, Guillette LJ Jr, Phelps SM. Androgens modulate song effort and aggression in Neotropical singing mice. Horm Behav. 2011, 59:90-97.

Pelletier G. Localization of androgens and estrogen receptors in rat and primate tissues. Histol Histopathol. 2000, 15:1261-1270.

Pennuto M, Rinaldi C. From gene to therapy in spinal and bulbar muscular atrophy: Are we there yet? Mol Cell Endocrinol. 2017 Jul 5.

Perez-Pouchoulen M, Toledo R, Garcia LI, Perez-Estudillo CA, Coria-Avila GA, Hernandez ME, Carrillo P, Manzo J. Androgen receptors in Purkinje neurons are modulated by 
systemic testosterone and sexual training in a region-specific manner in the male rat. Physiol Behav. 2016, 156:191-198.

Pettorossi VE, Di Mauro M, Scarduzio M, Panichi R, Tozzi A, Calabresi P, et al. Modulatory role of androgenic and estrogenic neurosteroids in determining the direction of synaptic plasticity in the CA1 hippocampal region of male rats. Physiol Rep. 2013, 1: e00185.

Phoenix CH, Goy RW, Gerall AA, Young WC. Organizing action of prenatally administered testosterone propionate on the tissues mediating mating behavior in the female guinea pig. Endocrinology 1959, 65:369-382.

Picot M, Billard JM, Dombret C, Albac C, Karameh N, Daumas S, Hardin-Pouzet H, Mhaouty-Kodja S. Neural androgen receptor deletion impairs the temporal processing of objects and hippocampal CA1-dependent mechanisms. PLoS One 2016; 11(2):e0148328.

Picot M, Naulé L, Marie-Luce C, Martini MA, Raskin R, Grange-Messent V, Franceschini I, Keller M, Mhaouty-Kodja S. Vulnerability of the neural circuitry underlying sexual behavior to chronic oral exposure to bisphenol A in male mice. Endocrinology 2014, $155: 502-512$

Pomerantz SM, Nunez AA, Bean NJ. Female behavior is affected by male ultrasonic vocalizations in house mice. Physiol. Behav. 1983, 31:91-96.

Pouliot WA, Handa RJ, Beck SG. Androgen modulates N-methyl-D-aspartate-mediated depolarization in CA1 hippocampal pyramidal cells. Synap N Y N. 1996, 23: 10-19.

Qiu L, Zhao Y, Guo Q, Zhang Y, He L, Li W, Zhang J. Dose-dependent regulation of steroid receptor coactivator-1 and steroid receptors by testosterone propionate in the hippocampus of adult male mice. J Steroid Biochem Mol Biol. 2016, 156:23-31.

Raskin K, de Gendt K, Duittoz A, Liere P, Verhoeven G, Tronche F, Mhaouty-Kodja S. Conditional inactivation of androgen receptor gene in the nervous system: effects on male behavioral and neuroendocrine responses. J Neurosci. 2009, 29:4461-4470. 
Raskin K, Marie-Luce C, Picot M, Bernard V, Mailly P, Hardin-Pouzet H, Tronche F, Mhaouty-Kodja S. Characterization of the spinal nucleus of the bulbocavernosus neuromuscular system in male mice lacking androgen receptor in the nervous system. Endocrinology 2012; 53:3376-3385.

Reader BF, Jarrett BL, McKim DB, Wohleb ES, Godbout JP, Sheridan JF. Peripheral and central effects of repeated social defeat stress: monocyte trafficking, microglial activation, and anxiety. Neuroscience 2015, 289:429-442.

Rizk A, Robertson J, Raber J. Behavioral performance of tfm mice supports the beneficial role of androgen receptors in spatial learning and memory. Brain Res. 2005, 1034:132-138.

Robinson S, Penatti CAA, Clark AS. The role of the androgen receptor in anabolic androgenic steroid-induced aggressive behavior in C57BL/6J and Tfm mice. Horm Behav. 2012, 61:67-75.

Ruka KA, Burger LL, Moenter SM. Both estrogen and androgen modify the response to activation of neurokinin-3 and $\kappa$-opioid receptors in arcuate kisspeptin neurons from male mice. Endocrinology 2016, 157:752-763.

Sakamoto H, Matsuda KI, Zuloaga DG, Hongu H, Wada E, Wada K, Jordan CL, Breedlove SM, Kawata M. Sexually dimorphic gastrin releasing peptide system in the spinal cord controls male reproductive functions. Nat Neurosci. 2008, 11:634-636.

Sakamoto H, Saito K, Marie-Luce C, Raskin K, Oti T, Satoh K, Tamura K, Sakamoto T, Mhaouty-Kodja S. Androgen regulates development of the sexually dimorphic gastrinreleasing peptide neuron system in the lumbar spinal cord: evidence from a mouse line lacking androgen receptor in the nervous system. Neurosci Lett .2014, 558:109-114.

Sato T, Matsumoto T, Kawano H, Watanabe T, Uematsu Y, Sekine K, Fukuda T, Aihara K, Krust A, Yamada T, Nakamichi Y, Yamamoto Y, Nakamura T, Yoshimura K, Yoshizawa 
T, Metzger D, Chambon $\mathrm{P}$, Kato $\mathrm{S}$. Brain masculinization requires androgen receptor function. Proc Natl Acad Sci U S A. 2004, 101:1673-1678.

Sato T, Matsumoto T, Yamada T, Watanabe T, Kawano H, Kato S. Late onset of obesity in male androgen receptor-deficient (AR KO) mice. Biochem Biophys Res Commun. 2003, 300:167-171.

Scordalakes EM, Rissman EF. Aggression and arginine vasopressin immunoreactivity regulation by androgen receptor and estrogen receptor alpha. Genes Brain Behav 2004, $3: 20-26$.

Schulz KM, Richardson HN, Zehr JL, Osetek AJ, Menard TA, Sisk CL. Gonadal hormones masculinize and defeminize reproductive behaviors during puberty in the male Syrian hamster. Horm Behav. 2004, 45:242-249.

Simerly RB, Chang C, Muramatsu M, Swanson LW. Distribution of androgen and estrogen receptor mRNA-containing cells in the rat brain: an in situ hybridization study. J Comp Neurol. 1990, 294:76-95.

Skucas VA, Duffy AM, Harte-Hargrove LC, Magagna-Poveda A, Radman T, Chakraborty G, et al. Testosterone depletion in adult male rats increases mossy fiber transmission, LTP, and sprouting in area CA3 of hippocampus. J Neurosci. 2013, 33:2338-2355.

Smith JT, Dungan HM, Stoll EA, Gottsch ML, Braun RE, Eacker SM, Clifton DK, Steiner RA. Differential regulation of KiSS-1 mRNA expression by sex steroids in the brain of the male mouse. Endocrinology 2005, 146:2976-2984.

Smith MR, Hamson DK, Poort JE, Jordan CL, Breedlove SM 2012 Ontogeny of androgen receptor expression in spinal nucleus of the bulbocavernosus motoneurons and their target muscles in male mice. Neurosci Lett. 2012, 513:119-123. 
Studer E, Näslund J, Andersson E, Nilsson S, Westberg L, Eriksson E. Serotonin DepletionInduced Maladaptive Aggression Requires the Presence of Androgens. PLoS ONE 2015 10(5):e0126462.

Swift-Gallant A, Coome LA, Ramzan F, Monks DA. Nonneural androgen receptors affect sexual differentiation of brain and behavior. Endocrinology 2016a, 157:788-798.

Swift-Gallant A, Coome L, Srinivasan S, Monks DA. Non-neural androgen receptor promotes androphilic odor preference in mice. Horm Behav. 2016b, 83:14-22.

Tsai HW, Taniguchi S, Samoza J, Ridder A. Age- and Sex-Dependent Changes in Androgen Receptor Expression in the Developing Mouse Cortex and Hippocampus. Neurosci J. $2015 ; 2015: 525369$.

Uchida M, Palmateer JM, Herson PS, DeVries AC, Cheng J, and Hurn PD. Dose-dependent effects of androgens on outcome after focal cerebral ischemia in adult male mice. J Cereb Blood Flow Metab. 2009, 29:1454-1462.

van Leeuwen FW, Caffe AR, De Vries GJ. Vasopressin cells in the bed nucleus of the stria terminalis of the rat: sex differences and the influence of androgens. Brain Res. 1985, 325:391-394.

Wersinger SR, Haisenleder DJ, Lubahn DB, Rissman EF. Steroid feedback on gonadotropin release and pituitary gonadotropin subunit mRNA in mice lacking a functional estrogen receptor alpha. Endocrine 1999, 11:137-143.

Wersinger SR, Rissman EF. Oestrogen receptor alpha is essential for female-directed chemoinvestigatory behaviour but is not required for the pheromone-induced luteinizing hormone surge in male mice. J Neuroendocrinol. 2000, 12:103-110.

Yamada S, Ohoya M, Takanami K, Matsuda KI, Kawata M. Critical role of androgen receptor in the postnatal period in male sexual behavior in rats. Neurosci Lett. 2015, 609:189-193. 
Yarbrough WG, Quarmby VE, Simental JA, Joseph DR, Sar M, Lubahn DB, et al. A single base mutation in the androgen receptor gene causes androgen insensitivity in the testicular feminized rat. J Biol Chem. 1990, 265:8893-8900.

Yeh S, Tsai MY, Xu Q, Mu XM, Lardy H, Huang KE, Lin H, Yeh SD, Altuwaijri S, Zhou X, Xing L, Boyce BF, Hung MC, Zhang S, Gan L, Chang C. Generation and characterization of androgen receptor knockout (ARKO) mice: an in vivo model for the study of androgen functions in selective tissues. Proc Natl Acad Sci U S A. 2002, 99:13498-13503.

Yu IC, Lin HY, Liu NC, Sparks JD, Yeh S, Fang LY, Chen L, Chang C. Neuronal Androgen Receptor Regulates Insulin Sensitivity via Suppression of Hypothalamic NF-kB-Mediated PTP1B Expression. Diabetes 2013, 62:411-423.

Zuloaga DG, Morris JA, Jordan CL, Breedlove SM. Mice with the testicular feminization mutation demonstrate a role for androgen receptors in the regulation of anxiety-related behaviors and the hypothalamic-pituitary-adrenal axis. Horm Behav. 2008, 54:758-766.

Zuloaga DG, Poort JE, Jordan CL, Breedlove SM. Male rats with the testicular feminization mutation of the androgen receptor display elevated anxiety-related behavior and corticosterone response to mild stress. Horm Behav. 2011, 60:380-388. 


\section{Figure Legends}

Figure 1. Neural $A R$ knockout males were generated by crossing $A R$ floxed mice (Exon 2 flanked by loxP sites; De Gendt et al., 2004) and transgenic animals carrying the Cre recombinase under the control of the promoter and neural enhancer of nestin (Tronche et al., 1999). The expression of the Cre recombinase in neural (neuronal and glial) cells triggers the excision of the AR Exon 2 (Raskin et al., 2009).

Figure 2. Simplified scheme of the neural circuitry underlying male sexual behavior. A-B. Pheromonal cues emitted by receptive females are detected by the olfactory system and signals are transmitted to the medial amygdala (MeA), bed nucleus of stria terminalis (BNST) and to the hypothalamic medial preoptic area (POA). C. Signals are also transmitted from the hypothalamus (paraventricular nucleus) to spinal areas involved in erection such as the spinal nucleus of the bulbocavernosus $(\mathrm{SBN})$. All these brain and spinal areas express the AR.

Figure 3. Behavioral analysis of neural $A R$ knockout males backcrossed for at least nine generations into strain C57BL/6. Both control and mutant littermates were castrated and supplemented with testosterone implants in order to normalize their hormonal levels as previously described (Raskin et al., 2012). Males ( $\mathrm{n}=12-15$ per genotype) were tested twice (Test 1: naïve, Test 2: sexually experienced) with a week-interval in the presence of receptive females (ovariectomized and primed with estradiol and progesterone). Two-way ANOVA showed a significant effect of genotype on the latencies to the first mount $\left(\mathrm{Mo:} \mathrm{F}_{(1,25)}=20.84\right.$, $\mathrm{p}=0.0001)$, thrust $\left(\mathrm{Th}: \mathrm{F}_{(1,25)}=26.45, \mathrm{p}<0.0001\right)$, intromission $\left(\operatorname{In}: \mathrm{F}_{(1,25)}=26.28, \mathrm{p}<\right.$ $0.0001)$ and to ejaculation $\left(E j: F_{(1,25)}=26.88, p<0.0001\right)$. There was also a significant effect of experience on Th $\left(\mathrm{F}_{(1,25)}=7.488, \mathrm{p}=0.0113\right)$, In $\left(\mathrm{F}_{(1,25)}=6.164, \mathrm{p}=0.0201\right)$ and $\mathrm{Ej}\left(\mathrm{F}_{(1,25)}\right.$ $=6.307, \mathrm{p}=0.0189)$. There was no amelioration of behavior induced by sexual experience in 
mutants by contrast to their control littermates, which exhibited reduced latency to ejaculation when sexually experienced. a, $\mathrm{p}<0.05$ vs control males; $\mathrm{b}, \mathrm{p}<0.05$ vs naïve males. 

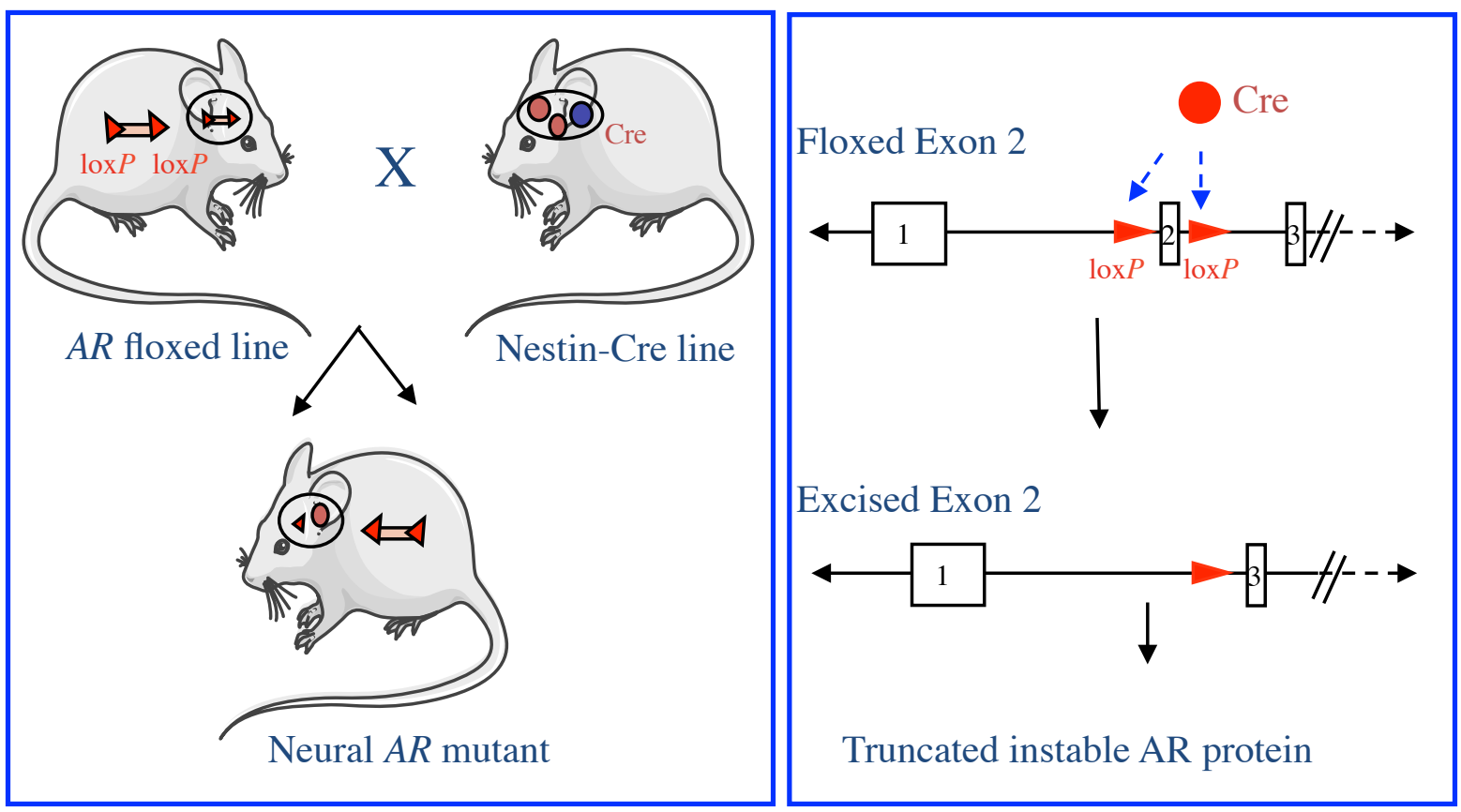

Figure 1 


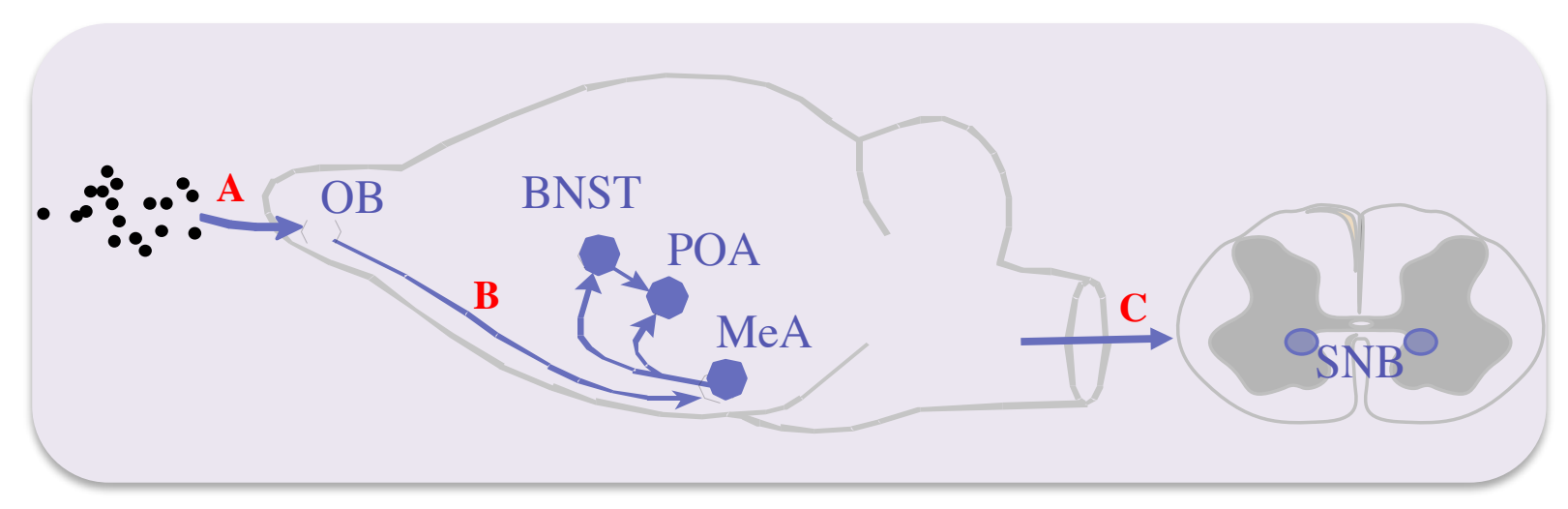

Figure 2 


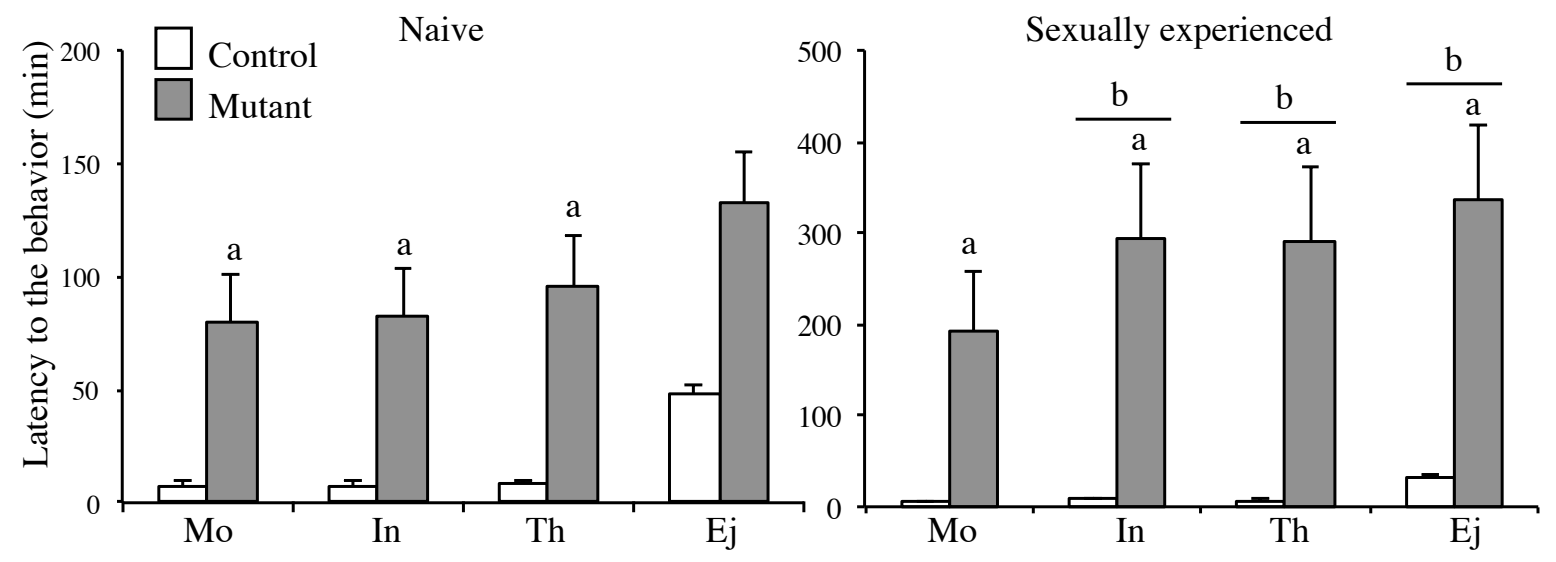

Figure 3 
Table 1

\begin{tabular}{|c|c|c|c|c|c|}
\hline \multirow[t]{2}{*}{$A R$ mutation } & \multicolumn{2}{|c|}{ Spontaneous } & \multicolumn{3}{|c|}{ Transgenic mouse lines crossed } \\
\hline & $T f m$ & Reference & Floxed AR & Cre recombinase & Reference \\
\hline \multirow{3}{*}{ Global } & Rat & Allison et al. 1971 & Exon 2 & ACTB-Cre & Yeh et al. 2002 \\
\hline & Mouse & Lyon \& Hawks, 1970 & Exon 1 & CMV-Cre & Sato et al. 2003; Sato et al. 2004 \\
\hline & & & Exon 2 & PGK-Cre ${ }^{\mathrm{m}}$ & De Gendt et al. 2004 \\
\hline $\begin{array}{l}\text { Neural knockout: } \\
\text { neuronal and glial }\end{array}$ & & & Exon 2 (De Gendt et al. 2004) & Nestin-Cre (Tronche et al. 1999) & $\begin{array}{l}\text { Raskin et al. } 2009 \text { (C57BL/6 x 129SvEv) } \\
\text { Juntti et al. } 2010 \text { (C57BL/6 x 129SvEv) } \\
\text { Raskin et al. } 2012 \text { (C57BL/6) } \\
\text { Marie-Luce et al. 2013 (C57BL/6) } \\
\text { Picot et al. } 2014 \text { (C57BL/6) } \\
\text { Picot et al. } 2016(\mathrm{C} 57 \mathrm{BL} / 6) \\
\text { Karlsson et al. } 2016(\mathrm{C} 57 \mathrm{BL} / 6) \\
\text { Chen et al. } 2016 \\
\text { Dombret et al. in press (C57BL/6) }\end{array}$ \\
\hline Neuronal knockout: & & & Exon 2 ( Yeh et al. 2002) & Synapsin-I-Cre (Cohen et al. 2001) & Yu et al. 2013 \\
\hline \multicolumn{3}{|l|}{$A R$ overexpression } & \multicolumn{2}{|c|}{ Transgenic mouse lines } & Reference \\
\hline
\end{tabular}

Genetic models used to delineate the role of AR in CNS functions. Models with global or selective (neural, neuronal) AR mutation or overexpression are presented. For each genetically engineered model, the two mouse lines crossed to induce Cre-loxP-mediated invalidation or overexpression are shown. The genetic background of mouse lines is indicated when available. ACTB: actin beta; AR: androgen receptor; CMV: cytomegalovirus, PKG: phosphoglycerate kinase-1; Tfm: Testicular feminization mutation. 


\section{Table 2}

\begin{tabular}{|c|c|c|c|c|c|}
\hline Region & $\begin{array}{l}\text { Neuronal } \\
\text { population }\end{array}$ & Dimorphism & Technique & $\begin{array}{l}\text { Effect of neural } \\
A R \text { deletion }\end{array}$ & Reference \\
\hline Preoptic nucleus & $\begin{array}{l}\text { Kisspeptin neurons } \\
\text { Calbindin neurons }\end{array}$ & $\begin{array}{l}\text { Cell number }(\mathrm{M}<\mathrm{F}) \\
\text { Cell number }(\mathrm{M}>\mathrm{F})\end{array}$ & IHC & $\begin{array}{l}\text { Unchanged } \\
\text { Unchanged }\end{array}$ & $\begin{array}{l}\text { Picot et al., } \\
2014\end{array}$ \\
\hline BNST & $\begin{array}{c}\text { AVP neurons } \\
\text { Galanin neurons }\end{array}$ & $\begin{array}{l}\text { Cell number }(\mathrm{M}>\mathrm{F}) \\
\text { Cell number }(\mathrm{M}>\mathrm{F})\end{array}$ & ISH & $\begin{array}{l}\text { Unchanged } \\
\text { Unchanged }\end{array}$ & $\begin{array}{c}\text { Marie-Luce et } \\
\text { al., } 2013\end{array}$ \\
\hline Septum & $\begin{array}{c}\text { AVP Fibers } \\
\text { Galanin Fibers }\end{array}$ & $\begin{array}{l}\text { Density }(M>F) \\
\text { Density }(M>F)\end{array}$ & IHC & $\begin{array}{l}\text { Unchanged } \\
\text { Unchanged }\end{array}$ & $\begin{array}{c}\text { Marie-Luce et } \\
\text { al., } 2013\end{array}$ \\
\hline Spinal cord & SNB motoneurons & $\begin{array}{c}\text { Cell number }(M>F) \\
\text { Soma size }(M>F) \\
\text { Dendritic arborization }(M>F)\end{array}$ & $\begin{array}{l}\text { Retrograde } \\
\text { labeling }\end{array}$ & $\begin{array}{l}\text { Unchanged } \\
\text { Reduced } \\
\text { Reduced }\end{array}$ & $\begin{array}{l}\text { Raskin et al., } \\
2012\end{array}$ \\
\hline Spinal cord & GRP neurons & $\begin{array}{c}\text { Cell number }(\mathrm{M}>\mathrm{F}) \\
\text { Fiber density }\end{array}$ & IHC & $\begin{array}{l}\text { Reduced } \\
\text { Reduced }\end{array}$ & $\begin{array}{c}\text { Sakamoto et al., } \\
2014\end{array}$ \\
\hline
\end{tabular}

Analysis of sexually dimorphic populations in brain (preoptic nucleus, BNST, septum) and spinal regions of male mice lacking the neural androgen receptor gene (AR; Raskin et al., 2009) and backcrossed onto the C57BL/6 strain. $\mathrm{M}>\mathrm{F}$ and $\mathrm{M}<\mathrm{F}$ designate cell number, soma size, fiber density or dendritic arborization, which are higher or lower, respectively, in males (M) compared to females (F) as previously shown (Breedlove et al., 1980; De Vries et al., 1990; Goldstein et al., 1990; Kauffman et al., 2007; Orikasa \& Sakuma, 2010; Sakamoto et al., 2008; van Leeuwen et al., 1985). AVP: arginine-vasopressin; BNST: bed nucleus of stria terminalis; GRP: gastrin-releasing peptide; IHC: immunohistochemistry; ISH: in situ hybridization; SNB: spinal nucleus of the bulbocavernosus. 